\title{
Board Gender Diversity and Cross-border Mergers and Acquisitions: Evidence from European Deals
}

\author{
Mario Ossorio \\ Assistant Professor of Management \\ Department of Economics \\ Università degli Studi Della Campania "Luigi Vanvitelli" \\ Corso Gran Priorato di Malta, 1, 81043, Capua (Ce) - Italy
}

\begin{abstract}
In recent years, regulators, scholars, and the business community have been calling for the gender gap on boards of directors to be reduced. The literature reveals that female directors and managers have a number of effects on both the working of organizations and their investment decisions. The present study analyzed the influence of female directors on the likelihood of firms making cross-border acquisitions. The study examined a sample of 128 acquisitions during the period 2015-2017 whose acquiring firms were listed European firms. The main finding was that female directors reduced the firm's likelihood to acquire a foreign target.
\end{abstract}

\section{Introduction}

Internationalization strategies are crucial for firms' competitiveness nowadays, for several reasons. First, declining local demand leads firms to pursue new opportunities in foreign markets in order to preserve their long-term survival. Second, the increasing integration of international markets encourages firms to undergo internationalization themselves in order to compete with other global players who may jeopardize the performance of local enterprises. In addition, internationalization entails experiential learning (Barkema \& Vermeulen, 1998), thereby increasing firms' knowledge base and capabilities, and in turn, their competitiveness. Internationalization strategies also confer a number of specific advantages linked to ownership, location, and internalization (Dunning, 1981) on the firms that adopt them, and reflect a gradual and incremental process (Johanson \& Vahlne, 1977).

However, expansion into foreign countries also entails high risks, costs, and uncertainty, and requires considerable resources and time before it can generate tangible payoffs (Liu, Lin, \& Cheng, 2011). Insufficient experience of operating in foreign markets (Sapienza et al., 2006), plus the liability of foreignness (Zaheer, 1995) and of newness (Stinchcombe, 1965), all increase the risks underlying internationalization strategies. As the literature points out, the success of strategies for expansion into foreign countries depends on the availability of internal resources and competences; knowledge, technology, commercial, and managerial competences are all relevant assets for firms operating in foreign markets.

Given these circumstances, boards of directors are a relevant source of human and relational capital that may benefit firms in terms of, on the one hand, providing critical input for their long-term survival (Pfeffer \& Salancik, 1978), and on the other,helping them through advice and counsel to formulate their strategies (Haunschild, 1993).

The aim of this study was to shed light on the effect of board gender diversity on firms' strategies for expansion into foreign markets through mergers and acquisitions (M\&As). In recent years, the business community, regulators, and academics have focused on the effect of board gender diversity on the strategic activities of firms. This attention has been triggered both by regulators' calls to reduce the gender gap in organizations and by corporate governance studies pointing to the fact that gender diversity confers several benefits on boards (Bianco et al., 2015). However, empirical findings show that the effect of having women directors on boards is still controversial (Joecks et al., 2014).

The theoretical perspective adopted in this paper is based on the resource-dependence view of firms (Pfeffer \& Salancick, 1978). Applying this theory, this study explored whether and to what extent the presence of women on boards of directors is a strategic resource that influences the likelihood of firms making cross-border acquisitions. Therefore, the question that this paper raises is this: "Does board gender diversity positively or negatively influence the likelihood of a firm making cross-border acquisitions?"

We analyzed a sample of 128 acquisitions during the period 2015-2017 whose acquiring firms were listed continental European firms. The results indicated that the presence of women on boards of directors lowered firms' propensity to 
make cross-border acquisitions. This study makes two contributions. First, the focus on the impact of women directors on cross-border M\&As offers new insights into the influence of demographic characteristics on the advisory role of boards. To date, although many studies have highlighted the relationship between board gender diversity and financial (Ayadi et al., 2015) and accounting (Mahadeo et al., 2012) performance, the impact of women directors on the achievement of strategic goals remains relatively unexplored, with the literature on this aspect still at a nascent stage of development. Accordingly, this study provides new information in the area of board gender diversity studies. Second, it adds new findings to the management literature on M\&As; by emphasizing that corporate governance, and in particular the presence of women in the boardroom, significantly affects cross-border M\&As, it extends the literature on external growth strategies.

The following section presents a literature review exploring competing hypotheses on the effect of female directors on the propensity of firms to make cross-border M\&As. The empirical analysis (including a description of the sample and the variables used) is contained in the third section. This is followed by a fourth section in which we present and discuss the results. The fifth and final section contains our concluding comments

\section{Literature Review and Hypotheses Development}

The resource-dependence view (henceforth, RDV) contends that organizations cannot survive independently of their external environment (Pfeffer \& Salancik, 1978). That is, external entities control the resources (e.g., employees, technology, financial resources) critical to the survival of firms and therefore generate uncertainties for organizations. Given these circumstances, an organization's main objective is to establish links with these entities in order to lower its dependency on them and to acquire the resources needed to compete in the long-run (Hillman et al., 2003). From an RDV perspective, directors of firms broker access to relevant information and expertise, constitute a means of communication with constituents of relevance, bring commitments of support from external organizations, and confer social legitimacy. Thus, the main functions of boards of directors are to give counsel to and advise organizations in the shaping and implementing of strategies, and to connect them with external organizations in order to acquire the necessary resources (Kroll, Walters, \& Le, 2007).

International growth realized through cross-border M\&As has many advantages with regard to the speed of the process and the lack of the risk associated with unknown markets. In fact, most information on local markets constitutes a tacit component (Hennart, 1993). Through strategies of external growth, firms are able to grow in foreign markets even if they do not have managerial expertise in internationalization (Graves \& Thomas, 2006). Cross-border acquisitions allows firms to acquire new managerial resources, avoiding their internal development and the difficulties associated with it (Barkema \& Vermeulen, 1998). Nevertheless, acquiring a firm operating in a foreign market is a very complex transaction (Gomez-Mejia et al., 2015). Managing transactions of this kind requires qualified managers and directors, and a boardroom that works quickly and effectively.

In this context, the presence of women in boardroom appears very beneficial for various reasons. First, women make boards more effective because, compared with their male counterparts, they gather more information for meetings (Pathan \& Faff, 2013), are more prone to asking questions (Bilimoria \& Wheeler, 2000), and are more likely to attend board meetings (Adams \& Ferreira, 2009). In addition, women are able to bring new insights into complex issues (Francoeur et al., 2008), as well as different values, know-how, expertise, and perspectives (Daily \& Dalton, 2003; Lara, et al., 2017). They are also more likely to have a non-management background that encompasses a broad portfolio of experience (Singh et al., 2008). Consequently, they improve transparency and enrich the information available. Their presence increases the diversity of the views of boards, which in turn improves their creativity and problem- solving skills (Terjesen et al., 2016). Accordingly, a more diverse board could benefit both the management of complex transactions, such as cross-border M\&As, and understanding of the complex dynamics characteristic of international markets.

Moreover, cross-border M\&As need external capital to finance the transaction. As Brown et al. (2002) pointed out, institutional investors are very prone to granting the capital needed to finance the internationalization of firms to organizations whose boards contain female directors. This is because women are seen to encourage good governance and the understanding of different cultures.

Lastly, profitable acquisitions require the organizations that are party to the transaction to open up their social networks (Gomez-Mejia et al., 2015). Female directors tend to display the specific behaviors, such as better networking and socialization skills, that help firms to reduce uncertainty around their dependence on the external environment (Bear et al., 2010). Scholars have pointed out that female managers' networks tend to be more diverse than those of their male counterparts (Ibarra, 1992, 1993). 
Thus, through their female directors and their relational traits, firms may have an advantage when it comes to connecting not just with female customers but also, more generally, with various stakeholders (Liu et al., 2014).

Hla: A higher ratio of women directors to men directors positively affects cross-border acquisitions

On the one hand, external growth strategies in international markets confer certain benefits, such as faster growth and long-term competitiveness. In addition, cross-border M\&As allow overseas growth, even if firms do not possess adequate management competences in internationalization (Graves \& Thomas, 2006). In fact, the acquisition of an operating firm provides the acquirer with new managerial resources (Hennart \& Park, 1993).

On the other hand, such transactions are riskier than domestic ones because they entail double-layered acculturation (Barkema et al., 1996). This riskiness is linked mostly to post-M\&A integration. In cross-border acquisitions, differences between acquiring firms and target firms relate to their organizational cultures and to their national cultures (Brouthers \& Brouthers, 2000), making the success of the transaction very risky. Furthermore, difficulties associated with post-merger integration can generate administrative conflicts (Sales \& Mirvis, 1984) and feelings of hostility that may jeopardize the success of the acquisition. In addition, differences in management approaches may negatively affect post-merger synergies and compromise the survival of the new entity (Datta et al., 1991).

For women, the potential risk of a failed transaction can be a primary disincentive to undertaking cross-border acquisitions. It has been found that compared with their male counterparts, women show affective reactions to risky situations (Croson \& Gneezy, 2009). That is, bad outcomes are perceived more negatively by women than by men, and therefore the former are less inclined to risk. Moreover, in similar contexts women tend to feel fear while men are more prone to experience anger (Grossman \& Wood, 1993). Anger as opposed to fear stimulates individuals to regard a gamble as less risky (Lerner et al., 2003).

Lastly, overconfidence is rarer in women than in men (Levi et al., 2014). This may be because the former judge their predictions about future events to be less precise (Barber \& Odean, 2001) or because they foresee future events less positively (Malmendier \& Tate, 2005). In addition, compared with their male counterparts women tend to feel that they are not sufficiently financially competent (Robichaud et al., 2007). Therefore, financial choices present an ideal setting in which to analyze women's propensity to take risky decisions. In this vein, mutual funds managed by women have been found to adopt investment strategies characterized by a lower level of unsystematic risk and more stable returns (Niessen \& Ruenzi, 2006). Elsewhere, Levi et al. (2014) found that the presence of women directors negatively affected both the likelihood of making an acquisition and the size of the bid premium. Finally, it has been found that female managers' risk aversion avoids the risk of overvaluing merger synergies and increases as investments become more ambiguous and uncertain (Schubert et al., 2000).

On the basis of the above review, the following hypothesis is proposed:

$H 1 b$ : A higher ratio of women directors to men directors negatively affects cross-border acquisitions

\section{Method}

\subsection{Sample}

The sample for this study was cross-border acquisitions conducted by listed continental European companies in the period 2015-2017. From the initial sample, firms operating in financial sectors and firms whose information was not available were excluded. The final sample consisted of 128 acquisitions. The acquiring firms were domiciled in Austria, Belgium, Denmark, Finland, France, Germany, Italy, Luxembourg, Netherlands, Norway, Portugal, Spain, Sweden, and Switzerland. The accounting data (including leverage, cash holdings, intangibles, ROA, and total assets) were extracted from Datastream Thomson Reuters. Data on acquisitions, firm ownership, and boards of directors were drawn from the Eikon Thomson Reuters database

\subsection{Variables and Their Treatment}

The dependent variable in the logit regressions was "Cross-border acquisition," a binary variable that were coded one if the acquiring and target firm countries were different and zero if they were the same.

The ratio of women to men directors, the independent variable, was calculated as the number of female directors scaled by the number of directors (Liao et al., 2015). The percentage of female directors was a proxy of board gender diversity. A series of control variables was included to control for the effect of female directors on the likelihood of making a cross-border M\&A. Since scholars have highlighted that cross-border acquisitions require financial support (Gomez-Mejia et al., 2015), Leverage was controlled for, defined as total debt divided by total assets. Leverage can increase the propensity to undertake an acquisition by encouraging firms to adopt risky investments; on the other hand, an excessive debt level may reduce the propensity to be a bidder by exhausting new debt-issuing capacity (Caprio et al., 2011). Return on assets (ROA) was calculated as earnings before interest, taxes, depreciation, and amortization (EBITDA) over total assets; ROA can increase the likelihood of making a cross-border acquisition because firms with a 
high ROA are more profitable and generate higher cash flow. The variable Cash Holdings was calculated as the ratio of cash plus short-term investments divided by total assets.

Cash-rich firms have a greater propensity for acquisitions than do other firms. In any case, high cash reserves may lead managers to adopt opportunistic behaviors and to use cash at their discretion (Jensen, 1986). Size, defined here as a firm's total assets, can increase new debt-issuing capacity, favoring the financing of external growth strategies. The variable Intangibles was calculated as the ratio of intangible assets, excluding goodwill, divided by total assets. The acquisition of firms operating in foreign markets allows acquiring firms to spread the fixed costs associated with innovation across a greater number of outputs (Rogers, 2004).

\section{Results and Discussion}

Table I presents the descriptive statistics and Pearson correlations. On average, cross-border M\&As represented 66 percent of the entire sample and boards were composed of $31 \%$ of women directors. The correlations indicate that multicollinearity was not a concern here, allowing the use of regression analysis.

Table II presents the results of the logit regression analysis. Model 1 shows a statistically significant association between the propensity for cross-border acquisition and the following control variables: ROA $(b=2.03$; $p<0.05)$ and Intangibles $(b=4.66 ; p<0.10)$. Model 2 represents the regression model testing the competing hypotheses $\mathrm{H} 1 \mathrm{a}$ and $\mathrm{H} 1 \mathrm{~b}$ : that is, whether having a higher ratio of women directors to men directors affects the likelihood of cross-border acquisition in a positive or negative way. The regression result showed that the ratio of women directors was negative and significant $(b=-0.04 ; p<0.10)$. Therefore, the results support Hypothesis $1 \mathrm{~b}$, which proposes that a higher percentage of women on boards negatively affects international expansion through external growth strategies. Model 2 also revealed a statistically significant association between the propensity for cross-border acquisition and the following control variables: ROA $(b=1.74 ; p<0.05)$ and Intangibles $(b=5.04 ; p<0.10)$.

This study suggests that the main features of cross-border M\&As and the approach of women to financing and investment decisions can be used to interpret these results. If, on the one hand, cross-border M\&As support the longterm competitiveness of firms, on the other they represent a risky investment decision because of the difficulties associated with post-transaction integration. More specifically, different national cultures, together with the different organizational cultures, make the integration phase very complex and risky. Distinct managerial styles and potential conflicts between acquirer and target may emerge, and therefore the risk of the transaction failing is very high. Higher numbers of female directors, who, compared with the male counterparts are characterized by higher aversion to risk, may influence the decision-making process in terms of discouraging boards to undertake such transactions. When women directors analyze the issues surrounding cross-border M\&As during board meetings, their risk aversion may cause them to over-rate the riskiness of internationalization through external growth strategy (Croson \& Gneezy, 2009), because of double-layered acculturation (Barkema et al., 1996); at the same time, they may undervalue the relevance of the relative benefits of expansion into foreign markets, such as growth and lasting competitiveness.

\section{Conclusion}

The results of this study have several implications for policymakers and shareholders. The main one relates to the effect of board gender diversity on firms' strategic behavior. The business community, policymakers, and academicians all advocate having more women on boards of directors. This study confirms the significant effect female directors have on firms' strategic choices, suggesting that if, on one hand, they are reluctant to undertake risky transactions, on the other they avoid the risk of overvaluing potential synergies arising from the merger of acquirer and target firms. Second, the results suggest that shareholders should be more aware of the significant impact that female directors have on firms' external growth strategies; they should carefully evaluate the appointment of each member and, ultimately, the composition of their entire board.

This work is not without limitations. Two in particular should be addressed by future scholars. First, the sample consisted of continental European acquiring firms, which are generally controlled by a majority owner (Faccio \& Lang, 2002). This may generate potential bias in terms of the effect of the presence of a family or State blockholder on acquisition behavior. Consequently, our ability to generalize the results to other countries, such as those in which the ownership structure of firms is more fragmented, is limited.

The second limitation is the fact that we examined transactions over a two-year period only (2015-2017), thereby restricting the number of transactions we could include. M\&A activity is characterized by behavior that is cyclical (Golbe \& White, 1993 ) and concentrated during certain periods rather than constant over time (Faulkner et al., 2012; Megginson et al., 2008); that is, activity increases for a certain period and then decreases significantly. Studies considering a longer period of time are more likely to be able to consider a greater number of transactions. 
Future research should analyze the effect of board gender diversity on industry-diversifying M\&A strategies, in order to compare the effect observed here with that in the context of international diversifying acquisitions.

When firms expand into different industries they tend to reduce organizational risk; therefore, the relationship between board gender diversity and acquisition behavior in that context could be different. In addition, future studies should consider the effect of female directors when they constitute a critical mass. Indeed, some studies have already pointed to a significant effect of women's presence in organizations where women represent a consistent minority.

\section{References}

Adams, R. B., \& Ferreira, D. (2009). Women in the boardroom and their impact on governance and performance. Journal of Financial Economics, 94, 291-309.

Ayadi, O. F., Ojo, A. T., Ayadi, M. F., \& Adetula, D. T. (2015). Gender diversity in the governance of the Nigerian securities market. Corporate Governance. The International Journal of Business in Society, 15(5), 734-746

Barber, B. M., \& Odean, T. (2001). Boys will be boys: Gender, overconfidence, and common stock investment. Quarterly Journal of Economics, 116(1), 261-292.

Barkema, H. G. \& Vermeulen, F. (1998). International expansion through start-up or acquisition: a learning perspective. Academy of Management Journal, Vol. 41 No. 1, pp. 7-26.

Bear, S., Rahman, N., \& Post, C. (2010). The impact of board diversity and gender composition on corporate social responsibility and firm reputation. Journal of Business Ethics, 97(2), 207-221

Bianco, M., Ciavarella, A., \& Signoretti, R. (2015). Women on corporate boards in Italy: The role of family connections. Corporate Governance: An International Review, 23(2), 129-144.

Bilimoria, D., \& Wheeler, J. V. (2000). Women corporate directors: current research and future directions. Women in management: Current research issues, 2, 138-163.

Brouthers, K. D. \& Brouthers, L.E. (2000). Acquisition or greenfield start-up? Institutional, cultural and transaction cost influences, Strategic Management Journal, Vol. 21 No. 1, pp. 89-97.

Brown, D. A. H., Brown, D. L., \& Anastasopoulos, V. (2002). Women on boards. Not just the right thing, but the "bright" thing. Paper presented at the Conference Board of Canada.

Caprio, L., Croci, E. \& Del Giudice, A. (2011). Ownership structure, family control, and acquisition decision. Journal of Corporate Finance, Vol. 17 No. 5, pp. 1636-1657.

Croson, R., \& Gneezy, U. (2009). Gender differences in preferences. Journal of Economic Literature, 47(2), 448-474.

Daily, C. M., \& Dalton, D. R. (2003). Women in the boardroom: A business imperative. Journal of Business Strategy, 24(5), 8-9

Datta, D. K. (1991). Organizational fit and acquisition performance: effects of post-acquisition integration. Strategic Management Journal, Vol. 12 No. 4, pp. 281-297.

Dunning, J. H. (1981). International production and the multinational enterprise. London, England: George Allen \& Unwin

Faccio, M., \& Lang, L. H. P. (2002). The ultimate ownership of Western European corporations. Journal of Financial Economics, 65(3), 365-395

Francoeur, C., Labelle, R., \& Sinclair-Desgagné, B. (2008). Gender diversity in corporate governance and top management. Journal of Business Ethics, 81(1), 83-95.

Golbe, D. \& White, L. (1993). Catch a wave: the time series behaviour of mergers. Review of Economics and Statistics, 75(3), 493-499.

Gómez-Mejía, L.R., Patel, P.C. \& Zellweger, T.M. (2015). In the horns of the dilemma: socioemotional wealth, financial wealth, and acquisitions in family firms. Journal of Management, 20(10), 1-29.

Graves, C. \& Thomas, J. (2006). Internationalization of Australian family businesses: a managerial capabilities perspective. Family Business Review, 19(3), 207-223.

Hillman, A. J., \& Dalziel, T. (2003). Boards of directors and firm performance: Integrating agency and resource dependence perspectives. Academy of Management Review, 28(3), 383-396

Haunschild, P. (1993). Interorganizational imitation: The impact of interlocks on corporate acquisition activity. Administrative Science Quarterly, 38(4), 564-592

Hennart, J. F. (1993). Explaining the swollen middle: why most transactions are a mix of market and hierarchy, Organization Science, Vol. 4 No. 4, pp. 529-547.

Ibarra, H. (1992). Homophily and differential returns: Sex differences in network structure and access in an advertising firm. Administrative Science Quarterly, 37, 422-447.

Ibarra, H. (1993). Personal networks of women and minorities in management: A conceptual framework. Academy of Management Review, 18, 56-87. 
Jensen, M.C. (1986). Agency costs of free cash flow, corporate finance and takeovers. American Economic Review, 76(2), (323-329).

Joecks, J., Pull, K., \& Vetter, K. (2014). Gender diversity in the boardroom and firm performance: What exactly constitutes a critical mass? Journal of Business Ethics, 118, 61-72.

Johanson, J., \& Vahlne, J. E. (1977). The internationalization process of the firm - A model of knowledge development and increasing foreign market commitments. Journal of International Business Studies, 8(1), 23-32.

Kroll, M., Walters, B. A., \& Le, S. A. (2007). The impact of board composition and top management team ownership structure on post- IPO performance in young entrepreneurial firms. Academy of Management Journal, 50(5), $1198-1216$

Lara, J. M. G., Osma, B. G., Mora, A., \& Scapin, M. (2017). The monitoring role of female directors over accounting quality. Journal of Corporate Finance, 45, 651-668

Lerner, J. S., Gonzalez, R. M., Small, D. A., \& Fischhoff, B. (2003). Effects of fear and anger on perceived risks of terrorism: A national field experiment. Psychological Science, 14(2), 144-150

Levi, M., Li, K., \& Zhang, F. (2014). Director gender and mergers and acquisitions. Journal of Corporate Finance, 28, 185-200.

Liao, L., Luo, L., \& Tang, Q. (2015). Gender diversity, board independence, environmental committee and greenhouse gas disclosure. The British Accounting Review, 47(4), 409-424.

Liu, Y., Lin, W. T., \& Cheng, K. Y. (2011). Family ownership and the international involvement of Taiwan's hightechnology firms: The moderating effect of high-discretion organizational slack. Management and Organization Review, 7(2), 201-222.

Mahadeo, J. D., Soobaroyen, T., \& Hanuman, V. O. (2012). Board composition and financial performance: Uncovering the effects of diversity in an emerging economy. Journal of Business Ethics, 105, 375-388.

Malmendier, U., \& Tate, G. (2005). CEO overconfidence and corporate investment. Journal of Finance, 60(6), 26612700 .

Megginson, W.L., Smart, S.B. \& Lucey, B.M. (2008), Introduction to Corporate Finance, South-Western Cengage Learning EMEA, London.

Niessen, A., \& Ruenzi, S. (2006). Sex matter: Gender and mutual funds. Paper presented at Financial Management Association Conference, Stockholm, Sweden

Pathan, S., \& Faff, R. (2013). Does board structure in banks really affect their performance? Journal of Banking \& Finance, 37, 1573-1589.

Pfeffer, J., \& Salancik, G. R. (1978). The external control of organizations: A resource dependence perspective. New York: Harper \& Row.

Robichaud, Y., Zinger, T. J., \& LeBrasseur, R. (2007).Gender differences within early stage and established small enterprise: An exploratory study. International Entrepreneurship and Management Journal, 3(3), 323-343.

Rogers, M. (2004). Networks, firm size and innovation. Small Business Economics, 22(2), 141-153

Sales, A.L. \& Mirvis, P.H. (1984). When cultures collide: issues in acquisition, in Kimberly, J.R. and Quinn, R.E. (Eds), New Futures: The Challenge of Managing Corporate Transitions, Dow-Jones-Irwin, Hamewood, IL, p. 107

Sapienza, H. J., Autio, E., George, G., \& Zahra, S. A. (2006). A capabilities perspective on the effects of early internationalization on firm survival and growth. Academy of Management Review, 31(4), 914-933.

Schubert, M., Brown, M., \& Brachinger, H. (2000). Gender specific attitudes towards risk and ambiguity: An experimental investigation. Center for Economic Research,Swiss Federal Institute of Technology, Zürich. Working Paper No.17.

Singh, V., Terjesen, S., \& Vinnicombe, S. (2008). Newly appointed directors in the boardroom: How do women and men differ? European Management Journal, 26, 48-58

Stinchcombe, A. L. (1965). Social structures and organizations. In J. G. March (Ed.), Handbook of organizations (pp. 142-193). Chicago, IL: Rand McNally.

Terjesen, S., Barbosa Couto, E., \& Francisco, P. M. (2016). Does the presence of independent and female directors impact firm performance? A multi-country study of board diversity. Journal of Management and Governance, 20(3), 447-483

Zaheer, S. (1995). Overcoming the liability of foreignness. Academy of Management Journal, 38(2), 341-363.

Table 1. Descriptive statistics and correlations.

\begin{tabular}{lllllllll}
\hline Variables & Mean & SD & 1 & 2 & 3 & 4 & 5 & 6 \\
\hline 236ross-border M\&As & 0.66 & 0.47 & & & & & &
\end{tabular}


2. Women directors $\quad \begin{array}{lll}0.31 & 11.86 & -0.32 * *\end{array}$ ratio

3. Leverage

$\begin{array}{llll}0.28 & 0.16 & 0.20 * & -0.21 *\end{array}$

4. Size (Ln)

23.75

1.27

$-0.15$

$-0.10$

$0.58 \quad 0.39$

5. ROA

0.11

0.10

0.16

$-0.08$

0.14

6. Intangibles

0.07

0.06

$\begin{array}{lll}0.14 & 0.05 & -0.04\end{array}$

$-0.18^{*}$

7. Cash holdings

$-0.18 \quad 0.0$

0.31

$\mathrm{N}=128 ; *, * *$ statistically significant at the 0.05 and 0.01 level.

Table 2. Logit regression (Cross-border Acquisition = 1)

\begin{tabular}{lcc}
\hline Variables & Model 1 & Model 2 \\
\hline Women directors ratio & & $-0.04^{*}$ \\
Leverage & 2.49 & 2.22 \\
Size (Ln) & -0.22 & -0.08 \\
ROA & $2.03^{* *}$ & $1.74^{* *}$ \\
Intangibles & $4.66^{*}$ & $5.04^{*}$ \\
Cash holdings & -2.55 & -0.57 \\
Chi-square & 19.14 & 22.35 \\
\hline
\end{tabular}

$\mathrm{N}=128 ; * \mathrm{p}<0.10 ; * * \mathrm{p}<0.05 ; * * *$

$\mathrm{p}<0.01$ 